\title{
Nutrient accumulation curves in fruits and nutrient export by seeds and hulls harvesting of physic nut (Jatropha curcas $L$.)
}

\section{Curvas de acúmulo de nutrientes em frutos e exportação pela colheita de sementes e cascas de pinhão-manso}

\author{
Rosiane de Lourdes Silva de Lima ${ }^{1 *}$; Valdinei Sofiatti ${ }^{2}$; \\ Carlos Alberto Vieira de Azevedo ${ }^{3}$; Jairo Osvaldo Cazetta ${ }^{4}$; \\ Genelicio Souza Carvalho Júnior ${ }^{5}$, Nair Helena Castro Arriel ${ }^{2}$
}

\begin{abstract}
There is little information on the nutritional management of physic nut (Jatropha curcas L.). This study aimed to measure the nutrients accumulation during the growth of fruits in physic nut and the nutrients export from the area due to seed harvest and hull removal. Fruits were harvested at different times (11, $19,27,35,43,51$, and 59 days after anthesis), in a completely randomized design with four replications. Nutrient content was measured in the whole fruit and in the hull and seed separately. Nutrients accumulate in the fruit during its growth. Nitrogen is the nutrient accumulated in the greatest amount, followed by potassium, calcium, phosphorus, magnesium, and sulfur. For the micronutrients, their content decreased in order of: zinc, manganese, copper, and iron. There was a high demand for $\mathrm{Ca}, \mathrm{Mg}, \mathrm{Cu}, \mathrm{Zn}$, and $\mathrm{Mn}$ in the early fruit development. The physic nut fruit requires significant amounts of micronutrients for normal fruit growth. Potassium is the nutrient exported in the greatest amount through a hull.
\end{abstract}

Key words: Jatropha curcas, export by harvest, mineral nutrition

\section{Resumo}

Há pouco conhecimento sobre o manejo nutricional de pinhão-manso (Jatropha curcas L.). Objetivouse com este trabalho medir o acúmulo de nutrientes ao longo do crescimento de frutos de pinhão-manso e a exportação de nutrientes da área devido à colheita de sementes e remoção das cascas. Frutos foram colhidos em diferentes momentos $(11,19,27,35,43,51$ e 59 dias após a antese) em delineamento inteiramente casualizado com quatro repetições. Para o estudo de exportação de nutrientes, o teor de nutrientes foi medido tanto nos frutos inteiros como na casca e semente separadamente. Os nutrientes se acumulam nos frutos ao longo do crescimento. O Nitrogênio é o nutriente acumulado em maior quantidade, seguido pelo Potássio, Cálcio, Fósforo, Magnésio e Enxofre. Dentre os micronutrientes, a quantidade acumulada nos frutos teve a seguinte ordem decrescente: Zinco, Manganês, Cobre e Ferro. No início do crescimento, houve grande demanda por $\mathrm{Ca}, \mathrm{Mg}, \mathrm{Cu}, \mathrm{Zn}$ e Mn. O pinhão-manso demanda quantidades expressivas de micronutrientes durante a formação dos frutos. Potássio é o nutriente exportado em maior quantidade pela casca do fruto.

Palavras-chave: Jatropha curcas, exportação pela colheita, nutrição mineral

\footnotetext{
${ }^{1}$ Pesquisadora Universidade Federal de Campina Grande, PNPD/CNPq/UFCG, Campina Grande, PB, Brasil. E-mail: limarosiane@, yahoo.com.br

${ }^{2}$ Pesquisadores, Embrapa Algodão, Campina Grande, PB, Brasil. E-mail: valdinei.sofiatti@embrapa.br; nair.arriel@embrapa.br

3 Prof., Universidade Federal de Campina Grande, Unidade Acadêmica de Engenharia Agrícola, Campina Grande, PB, Brasil. E-mail: carlos@deag.ufcg.edu.br

${ }^{4}$ Bolsista da Embrapa Algodão, Mestre em Ciências Agrárias, Universidade Estadual da Paraíba, UEPB. Paraíba, PB, Brasil. E-mail: carvalhogenelicio@yahoo.com.br

5 Prof., Dept ${ }^{\circ}$ de Tecnologia, UNESP, Universidade Estadual Paulista “Júlio de Mêsquista Filho”, UNESP, Jaboticabal, SP, Brasil. E-mail: cazetta@fcav.unesp.br

* Author for correspondence
} 


\section{Introduction}

The production of physic nut has been considered a promising source of oil for biodiesel production (MAES et al., 2009; NOOR CAMELLIA et al., 2009). This is a perennial crop, and commercial production is initiated on the second year after planting, and stabilized from the fourth or fifth year onward.

According to Laviola and Dias (2008), when the physic nut is planted in the beginning of the rainy season in the Zona da Mata of Minas Gerais, the crop initiates its production in the first year, and, although stability is achieved in the fourth year, the plant has the potential to produce fruits for more than 40 years, without the need for renewing the crops.

Although robust, the plant has a slow growth and exhibits symptoms of nutritional deficiency, which is visible when cultivated in soil poor in macronutrients such as $\mathrm{N}$, $\mathrm{P}$, and $\mathrm{K}$ (MAIA et al., 2011), and micronutrients such as $\mathrm{B}, \mathrm{Fe}, \mathrm{Mn}$, and Mo (SILVA et al., 2009). The crop responds to fertilization with nitrogen, phosphorus, and potassium (MARTINS et al., 2009; SOUZA et al., 2011) and to organic fertilization (JUWARKAR et al., 2008; CUEVAS, 2009; KUMAR et al., 2009). Both these types of fertilization should be performed according to soil fertility; otherwise plants will have a slow growth and lower number of branches, which implies lower productivity since fruits are produced at the tip of the branches. Therefore, correct fertilization is essential to promote fast vegetative growth and allow the formation of structures and adequate nutritional reserves to support rewarding and early productivity.

It has been shown that physic nut is demanding in macro- and micronutrients (LAVIOLA \& DIAS, 2008), with the leaves showing nutrient accumulation in the following order: $\mathrm{N}>\mathrm{Ca}>\mathrm{K}$ $>\mathrm{Mg}>\mathrm{P}>\mathrm{S}>\mathrm{Mn}>\mathrm{Fe}>\mathrm{B}>\mathrm{Zn}>\mathrm{Cu}$. The N/K ratio in the leaf is 2.3 in the flowering period, and 1.4 in the fruits, indicating that the crop increases its requirement for potassium in the production phase. According to these authors, in plantations with $4 \mathrm{~m}$ $\times 2 \mathrm{~m}$ spacing, when plants produce up to $4 \mathrm{~kg}$ of seeds plant ${ }^{-1}$ annually, it is possible that the nutrient export in fruits corresponds to approximately $\mathrm{N}$ 146, $\mathrm{P}_{2} \mathrm{O}_{5} 66, \mathrm{~K}_{2} \mathrm{O} 124, \mathrm{CaO} 81, \mathrm{MgO} 45$, and $\mathrm{S}$ $5 \mathrm{~kg} \mathrm{ha}^{-1}$, for and B 162, Cu 75, Mn 667, and $\mathrm{Zn}$ $136 \mathrm{~g} \mathrm{ha}^{-1}$, for micronutrients. If an annual nutrient replacement is not performed, soil depletion and reduction in crop productivity will occur.

In order for the physic nut to be able to develop all its production potential, all technological steps have to be established, including the nutrient management. With better insight about the nutritional state of the crop, it will be possible to verify and monitor if the fertilization management is effective by monitoring the nutrient content in leaves through regular analysis of the leaves (MARSCHNER, 2002). Another viable alternative to evaluate the nutrient demand of a crop is to assess the quantities of extracted and exported nutrients through harvesting during the plant cycle (MESQUITA et al., 2010).

The aim of this work was to evaluate the accumulation of nutrients in physic nut fruits at different phases of growth, and the export of macroand micronutrients by collecting fruits, hulls, and seeds during harvest.

\section{Materials and Methods}

Healthy physic nut plants were selected during their flowering period in a homogeneous area of four-year-old plants, cultivated at the spacing of 3 $\times 1 \mathrm{~m}$ and belonging to a seed production farm at the Fazenda Estivas, located in the municipality of Garanhuns, PE ( $8^{\circ} 56^{\prime} \mathrm{S}, 36^{\circ} 27^{\prime} \mathrm{W}, 741 \mathrm{~m}$ altitude). The monthly average rainfall of the region is 130 $\mathrm{mm}$, and the climate is semiarid (BS; dry, semiarid, megathermal, with four rainy months) according to the Köppen classification. The precipitation and temperature measured during the year the experiment was carried out are shown in Figure 1. 
Figure 1. Precipitation and temperature registered in the period from January to December 2010.

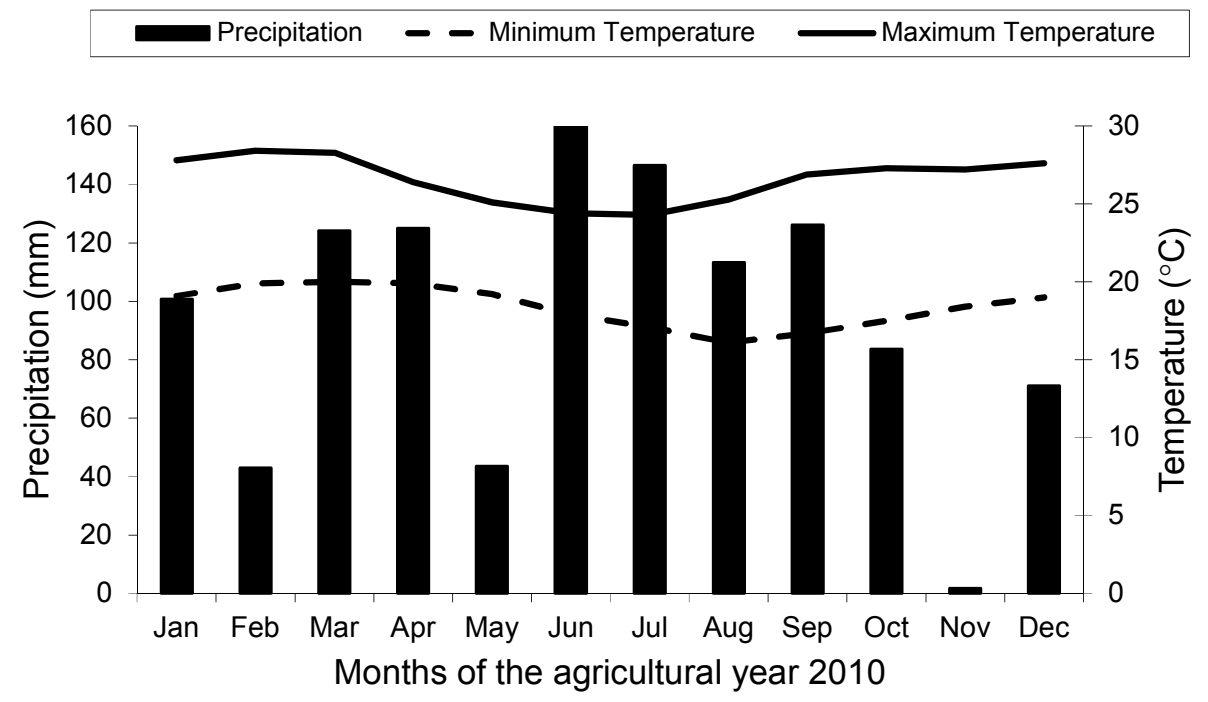

Source: Elaboration of the authors.

The soil in the study area is classified as Neossolo Regolitico (Regosols) with a sandy consistency. Samples for chemical analysis were collected at a depth of 0-20 cm in the shrubs' canopy projection zone. The samples were homogenized and analyzed at the Irrigation and Salinity Laboratory of the Federal University of Campina Grande (UFCG). The soil was slightly acidic ( $\mathrm{pH}$ 6.2) and with 76\% of base saturation (Table 1).

Table 1. Soil characteristics in the physic nut cultivating area.

\begin{tabular}{lccccccccccc}
\hline $\mathrm{pH}$ & $\mathrm{Ca}^{2+}$ & $\mathrm{Mg}^{2+}$ & $\mathrm{Na}^{+}$ & $\mathrm{K}^{+}$ & $\mathrm{S}$ & $\mathrm{H}+\mathrm{Al}$ & $\mathrm{Al}^{3+}$ & $\mathrm{T}$ & $\mathrm{V}$ & $\mathrm{P}$ & O.M. \\
\hline $1: 2.5$ & \multicolumn{8}{c}{ Exchange complex $\left(\mathrm{mmol}_{c} \mathrm{dm}^{-3}\right)$} \\
\hline 6.2 & 25.7 & 14.3 & 1.47 & 2.3 & 43.7 & 14.0 & 0.5 & 57.7 & 76 & 11.4 & 14.7 \\
\hline
\end{tabular}

S: Sum of bases; T: Effective CEC (T); V: Base saturation; O.M.: organic matter.

Liming was not necessary before the seedlings were planted in the fields, or in the following years. However, during the 4 years of cultivation, annual fertilization was carried out with the application of 6 $\mathrm{t} \mathrm{ha}^{-1}$ of organic matter in the form of cattle manure, in doses recommended by soil analysis.

For the nutrient accumulation and export curves, the analyses was performed separately for the data in a completely randomized design, and the treatments comprised different seasons of fruit harvesting (11, 19, 27, 35, 43, 51, 59 days after anthesis; DAA), with 4 repetitions, and 2 samples per plot, which were submitted to regression analysis. In order to conduct the nutrient export studies, the treatments comprised the whole fruits, hulls, and seeds, which were analyzed in a design and repetitions similar to the previous mentioned analyses. The differences between the treatments of the export study were assessed with the means tests.

For determining the nutrient content of the fruits and subsequent calculation of accumulated macroand micronutrients, 50 fresh fruits were collected at different growth stages from 10 studied plants, which were immediately washed using deionized 
water, weighted to determine their fresh weight, dried in a forced convection- incubator until reaching a constant weight, and then, weighted again in order to calculate the dry mass.

At fruit maturation (approximately 70 DAA), the physic nut fruits were collected, washed, dried and shelled, and separated into hulls and seeds in order to determine the nutrient quantity that is removed from the area of cultivation through fruit, seed, and hull harvest.

The plant samples were identified, washed in deionized water to remove impurities, placed in paper bags, dried in a forced convection incubator at $70^{\circ} \mathrm{C}$, milled using a Wiley mill, and stored in polyethylene containers with a hermetic seal. The content of $\mathrm{P}, \mathrm{K}, \mathrm{Ca}, \mathrm{Mg}$, and $\mathrm{S}$ was determined after nitric-perchloric digestion, and the $\mathrm{N}$ content with sulfuric digestion. The samples submitted to sulfuric digestion were used in the analyses to determine the nitrogen content, whereas samples prepared by nitric-perchloric digestion were used in the analyses to determine $\mathrm{P}, \mathrm{K}, \mathrm{Ca}, \mathrm{Mg}, \mathrm{S}, \mathrm{Fe}, \mathrm{Cu}$, $\mathrm{Zn}$, and Mn content.

The $\mathrm{N}$ content was determined by Nessler colorimetric method, P content by phosphomolybdate reduction with ascorbic acid assay modified by Braga \& Delfelipo (1974), and $\mathrm{K}$ content by flame photometry. $\mathrm{Ca}, \mathrm{Mg}, \mathrm{Cu}, \mathrm{Fe}$, $\mathrm{Mn}$, and $\mathrm{Zn}$ were determined by atomic absorption spectrophotometry, and S by sulphate turbidimetry (BLANCHAR et al., 1963).
The assessment of nutrient accumulation in different parts of the fruits was obtained by calculating the nutrient quantity $\left(\mathrm{Q}_{\mathrm{N}}\right)$ using the equation (1).

$\mathrm{Q}_{\mathrm{N}}=$ (nutrient content $\times$ dry matter $\times$ number of fruits plant ${ }^{-1} \times$ number of plants ha ${ }^{-1}$ ).

The results of the macronutrients were presented in $\mathrm{kg} \mathrm{ha}^{-1}$ and micronutrients in $\mathrm{g} \mathrm{ha}^{-1}$. These values were used to calculate the percentage of exported nutrients per ton of fruits, seeds, and hulls.

The obtained values were submitted to the analysis of variance (F-test) and polynomial regression according to the recommendations by Santos and Gheyi (2003).

\section{Results and Discussion}

The fruits diameter, as well as the dry mass accumulation, increased linearly during the fruit growth phase (Table 2). The accumulation of all macronutrients followed the accumulation curves of dry-mass gain and increase in fruit diameter (Table 2).

Despite the significant linear effects observed for $\mathrm{N}, \mathrm{P}, \mathrm{K}, \mathrm{Ca}, \mathrm{Mg}$, and $\mathrm{S}$ macronutrients, the quadratic model was the mathematical model that best fit $\mathrm{N}, \mathrm{P}, \mathrm{K}$, and $\mathrm{S}$.

Table 2. Summary of the analysis of variance of the fruits diameter (FD), accumulation of dry mass (ADM), and accumulation of $\mathrm{N}, \mathrm{P}, \mathrm{K}, \mathrm{Ca}, \mathrm{Mg}$, and $\mathrm{S}$ in the dry mass of physic nut fruits at different growth phases.

\begin{tabular}{llllllllll}
\hline \multirow{2}{*}{ S.V. } & \multirow{2}{*}{ D.F } & \multicolumn{9}{c}{ Mean square } \\
\cline { 3 - 10 } & & FD & ADM & N & P & K & Ca & Mg & S \\
\hline Treatments & 6 & $139.78^{* *}$ & $0.18^{* *}$ & $218.31^{* *}$ & $6.45^{* *}$ & $47.59^{* *}$ & $11.89^{* *}$ & $1.11^{* *}$ & $0.23^{* *}$ \\
Linear & 1 & $828.19^{* *}$ & $1.05^{* *}$ & $1158.88^{* *}$ & $32.57^{* *}$ & $253.68^{* *}$ & $69.54^{* *}$ & $5.46^{* *}$ & $1.26^{* *}$ \\
Quadratic & 1 & $2.49^{\text {ns }}$ & $0.02^{* *}$ & $71.38^{* *}$ & $5.17^{* *}$ & $25.04^{* *}$ & $0.56^{\text {ns }}$ & $0.03^{\text {ns }}$ & $0.11^{* *}$ \\
Deviation & 4 & $2.00^{*}$ & $0.004^{*}$ & $19.89^{*}$ & $0.25^{* *}$ & $1.70^{*}$ & $0.31^{\text {ns }}$ & $0.29^{*}$ & $0.01^{\text {ns }}$ \\
Residue & 21 & 0.67 & 0.001 & 6.06 & 0.05 & 0.56 & 0.25 & 0.09 & 0.01 \\
\hline CV $(\%)$ & - & 4.95 & 10.52 & 27.16 & 15.24 & 16.58 & 18.00 & 25.85 & 36.45 \\
\hline
\end{tabular}

Results of ANOVAs, with the $\mathrm{F}$ test $(\mathrm{F})$ significance, are shown: $* * \mathrm{P}<0.01, * \mathrm{P}<0.05$, ns $\mathrm{P}>0.05$; CV $(\%)=\mathrm{Coefficient}$ of Variation. Source: Elaboration of the authors. 
Both the accumulation of dry mass and diameter of physic nut fruits increased linearly with the changes in the fruits growth phase (Figures $2 \mathrm{~A}$ and $2 \mathrm{~B})$. The fruits were initially collected with approximately $7.8 \mathrm{~mm}$ and $0.76 \mathrm{~g}$ of fresh mass, which corresponds to the fruit set phase according to the literature. This phase occurs soon after flowering and is characterized by intense cellular division, and during this process, increases in fruit size and dry mass can be observed as shown in Figure 2, the drymass gain and increase in fruit diameter were linear and significant.

Figure 2. Accumulation of dry mass (g) (A) and diameter of fruits (mm) of physic nut (B) at different growth phases.

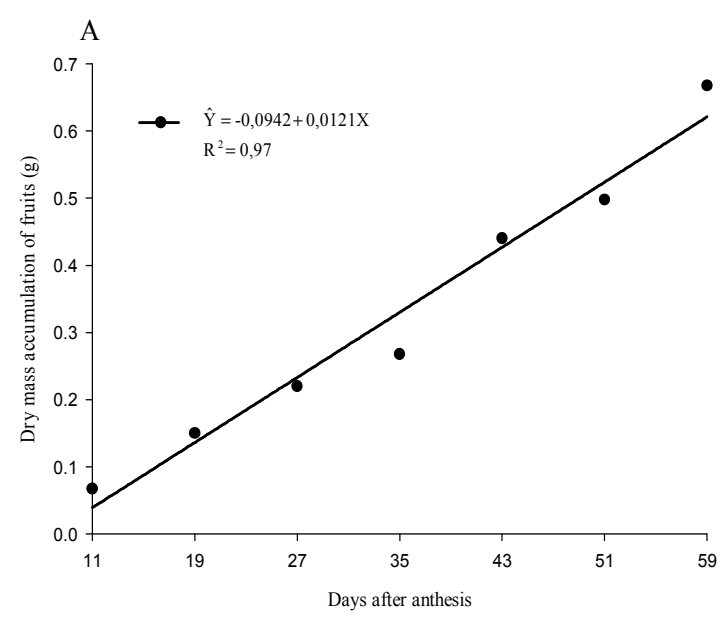

Source: Elaboration of the authors.

In the cellular elongation phase, which according to Santos et al. (2010) generally occurs between 8 and 40 DAA, we observed the same tendency in both dry mass gain and increase in diameter as observed in the first phase of fruit growth. The increase in the accumulation of dry mass in the elongation phase is mainly associated to the rapid expansion and elongation of cells, with deposition of wall material (MARSCHNER, 2002); during this process the water flow to the fruits is essential (MARENCO and LOPES, 2005). It is possible that in this phase, the endosperm filling process (grain filling) of the physic nut fruits also occurs. The grain

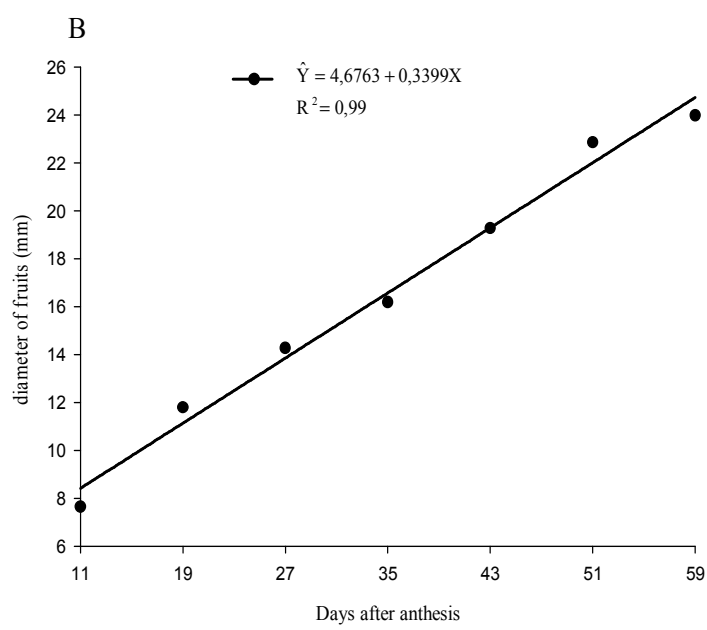

filling stage is characterized by the deposition of reserve substances mainly in the seeds, which reach their final dry-mass when the fruits are still green (RENA et al., 2001). Our results indicate that the endosperm filling of the physic nut fruits probably initiates soon after the cellular elongation phase and extends until approximately 50 to 60 DAA, when the fruit ceases to grow and changes its color from dark green to light green. After 10 days, fruits attain a yellow pigmentation, which then changes to brown and subsequently to black, when the fruits have totally dried (Figure 3). 
Figure 3. Evolution of maturation phases in physic nut fruits. (A) Complete development phase of the fruit, (B) Beginning of the maturation process, (C) Maturation of the fruits completed, (D) Process of water loss in fruits, (E) Final phase in maturation and natural drying of the fruits.
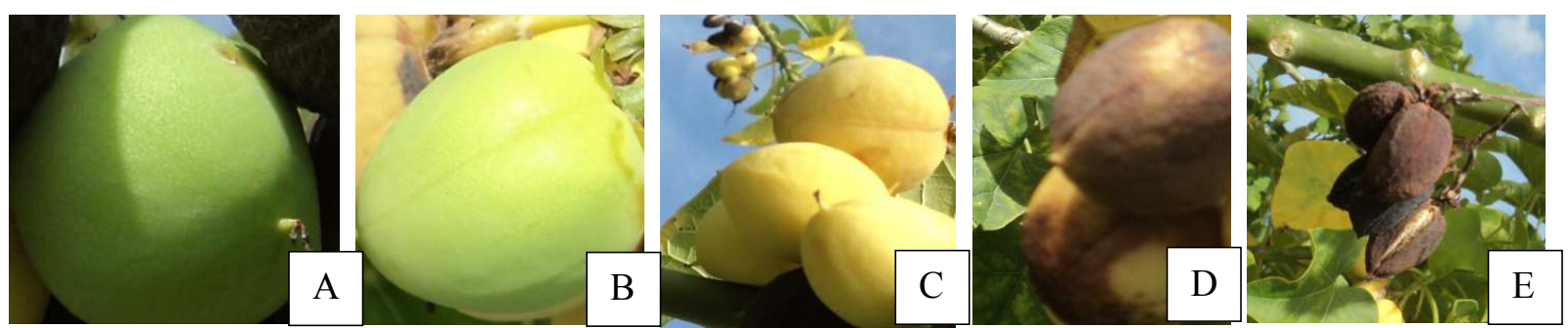

Source: Elaboration of the authors.

The accumulation of macro- and micronutrients $(\mathrm{N}, \mathrm{P}, \mathrm{K}, \mathrm{Ca}, \mathrm{Mg}, \mathrm{S}, \mathrm{Cu}, \mathrm{Fe}, \mathrm{Mn}$, and $\mathrm{Zn}$ ) in the physic nut fruits was relatively low in the first phase of growth until 27 DAA, increasing considerably with the fruit growth until maturation (Figures 4 and 5). Overall, in the first four weeks after fruits formation (until 27 DAA), there was a slow accumulation of N, P, K, S, and Fe (Figures 4A, 4B, 4C, 4F, and 5B); then, between the fourth and fifth week (between 27 and 35 DAA), the accumulation of these nutrients remained very slow but continuous. From the sixth week after fruit formation, there was an increase in the accumulation of these nutrients, and this tendency was maintained until the maturation of the fruits (59 DAA) (Figure 4).

The accumulation of nitrogen, phosphorus, potassium, and sulfur in the fruit differed with the growth phase. In the first 27 DAA, we observed a slow accumulation of these nutrients in fruit tissues of this oleaginous plant (Figures 4A, 4B, 4C, and $4 \mathrm{~F})$. This phase is characterized by an intense cellular division and elongation process in these tissues (MOURA et al., 2003; SANTOS et al., 2010). After this phase, a marked rise in the requirement of these nutrients by fruits was observed until its complete maturation, which occurred at 59 DAA (Figure 4). It is likely that the nutrient accumulation in fruits during the expansion stage occurs through mass flow, arising from the high rate of water translocation into the fruits in this stage (RAMIREZ et al., 2002), which is required for cellular expansion (TAIZ and ZEIGER, 2009).

Nitrogen was the nutrient that was accumulated the most by the fruits during the cycle until their maturation (Figure 4A). In order to produce a ton of mature fruits, on average, the plant removed 28 $\mathrm{kg}$ of nitrogen $\mathrm{ha}^{-1}$ from the soil. For most crops, $\mathrm{K}$ is the most exported nutrient by the fruits at the time of harvest. In the physic nut crop, we observed that this is the second most exported nutrient by the fruits during the cycle. The highest requirement for this nutrient occurred from 37 DAA until the fruit maturation. The seed filling stage is the moment when the crop requires the most these nutrients. It is recommended that the last fertilizing step should occur before this phase of fruit growth in order to meet the metabolic demands of fruit production. 
Figure 4. Accumulation curves of $\mathrm{N}, \mathrm{P}, \mathrm{K}, \mathrm{Ca}, \mathrm{Mg}$, and $\mathrm{S}\left(\mathrm{kg} \mathrm{ha}^{-1}\right)$ by the physic nut fruits at different growth phases.

A
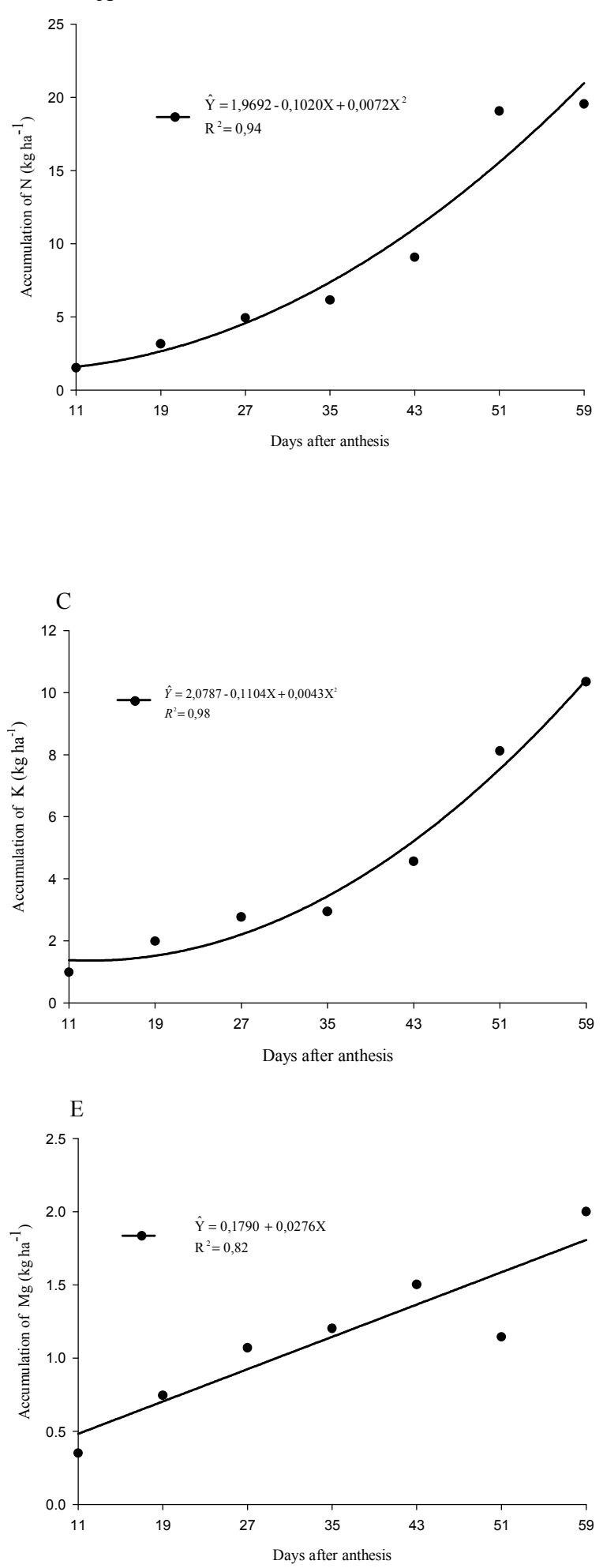

B

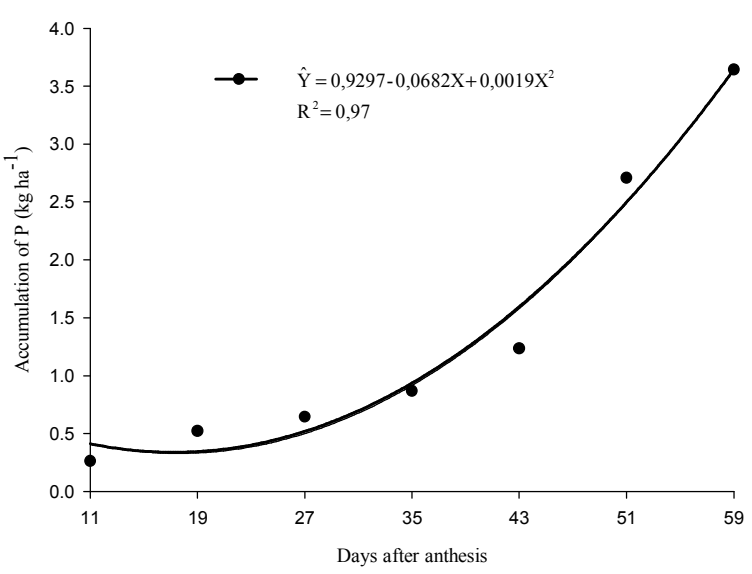

$\mathrm{D}$
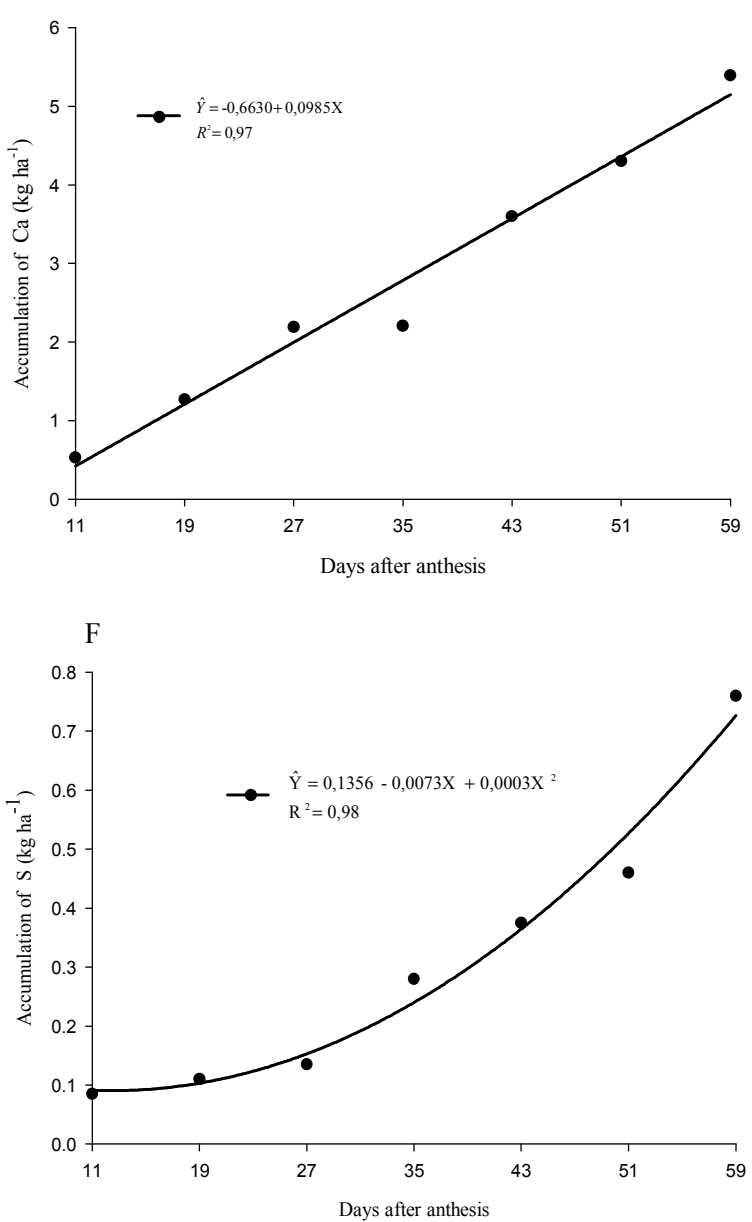

Source: Elaboration of the authors. 
With regard to $\mathrm{P}$ (Figure 4B), we observed a similar tendency as in $\mathrm{N}$, and the accumulation of this mineral was slower until 35 DAA. As shown in Figure 4B, the accumulation of $\mathrm{P}$ in fruit tissues increased after 35 DAA and until their maturation. One possible explanation for this is that metabolic processes such as endosperm filling, fatty acids production, and fruit maturation occur during this phase of fruit growth. Phosphorus is a nutrient in high demand by physic nut, since it promotes root growth (LIMA et al., 2011a; PRATES et al., 2012), flowering, fruit development (PEREIRA et al., 2011), and production of fatty acids (SOUSA et al., 2012). Phosphorus is accumulated in younger leaves and its levels tend to reduce due to its redistribution to the fruits (LIMA et al., 2011b).

The accumulation of $\mathrm{K}$ (Figure 4C) followed a quadratic behavior, also found in $\mathrm{N}$ and $\mathrm{P}$. The export of this nutrient was considerably slow in the first phase of fruit growth until the first 27 DAA. It is possible that in this phase, only the cellular division and elongation processes occur, with no need for higher energy consumption in metabolic processes. From the 27 DAA, there was a rapid increment in the amount of $\mathrm{K}$ removed by the physic nut fruits, reaching an export peak at 59 DAA, when fruits reached the end of the cycle. The comparison of the amounts of $\mathrm{K}$ and $\mathrm{N}$ removed by the physic nut shows that $\mathrm{K}$ is the second most required nutrient, after $\mathrm{N}$.

Potassium is a highly mobile nutrient (MARSCHNER, 2002), and even in environmental conditions that do not promote its absorption from the soil, this nutrient may be mobilized from other parts of the plant during the whole cycle. In addition, $\mathrm{K}$ is a nutrient required in the activation of diverse enzymes that are essential for synthesis of organic compounds including soluble sugars (MARSCHNER, 2002; MARENCO; LOPES, 2005), which are synthesized during the fruits' maturation.

With regard to $\mathrm{Ca}$ and $\mathrm{Mg}$ (Figures $4 \mathrm{D}$ and
4E), we observed an opposite behavior to that demonstrated by N, P, and $\mathrm{K}$. The accumulation of $\mathrm{Ca}$ and $\mathrm{Mg}$ in physic nut fruits was linear, gradually increasing with the fruit growth. The accumulation of $\mathrm{Ca}$ and $\mathrm{Mg}$ in the first phases of fruit growth was very high when compared to the accumulation of $\mathrm{N}$, $\mathrm{P}$, and K. It is likely that higher accumulation of $\mathrm{Ca}$ in this stage is associated to the fact that this nutrient is very important in cellular division processes and membrane and cell wall stabilization of newly formed cells (MARSCHNER, 2002; MARENCO and LOPES, 2005). Regarding Mg, this nutrient may be required in high quantity in order to accelerate ATPase activity (MARSCHNER, 2002), since the fruit at the fruit-set phase has a high respiratory rate (RENA et al., 2001).

The accumulation of S (Figure 4F) followed the same tendency shown by N, P, and K. In the first 27 DAA, there was a slow accumulation of this nutrient in the fruit tissues. In this growth phase, it is possible that intense cellular division, differentiation, and elongation processes occur. From the $27 \mathrm{DAA}$, an increase in the demand of this nutrient was observed that continued until the fruits maturation. Sulfur is mainly used in protein composition and in structural compounds of the cell (MARSCHNER, 2002). The beginning of fruit formation did not have an impact on the accumulation of this nutrient, but during the fruit growth phase, there was a high demand for $\mathrm{S}$ until the maturation was reached.

The accumulation of micronutrients presented a linear and quadratic response, and it better adjusted to the linear model (Table 3). The accumulation of $\mathrm{Cu}, \mathrm{Fe}, \mathrm{Mn}$, and $\mathrm{Zn}$ was high, showing a linear increase from the first phase of fruit growth (Figures $5 \mathrm{~A}, 5 \mathrm{~B}, 5 \mathrm{C}$, and 5D). Higher accumulation of these nutrients occurred at 59 DAA, when the fruits reached a mean weight and diameter of $0.67 \mathrm{~g}$ and $23.9 \mathrm{~mm}$, respectively. In the first growth phase, which comprises the fruit-set phase, the fruits had the average weight and diameter of $0.06 \mathrm{~g}$ and 7.8 $\mathrm{mm}$, respectively. 
Table 3. Summary of the analysis of variance of $\mathrm{Cu}, \mathrm{Fe}, \mathrm{Mn}$, and $\mathrm{Zn}$ accumulation in the dry mass of the physic nut fruits at different growth phases.

\begin{tabular}{llllll}
\hline \multirow{2}{*}{ S.V. } & \multirow{2}{*}{ D.F } & \multicolumn{4}{c}{ Mean square } \\
\cline { 3 - 6 } & & $\mathrm{Cu}$ & $\mathrm{Fe}$ & $\mathrm{Zn}$ & $\mathrm{Mn}$ \\
\hline Treatments & 6 & $9.88^{* *}$ & $175.0342^{* *}$ & $221.19^{* *}$ & $27.69^{* *}$ \\
Linear & 1 & $55.15^{* *}$ & $914.23^{\text {ns }}$ & $1272.71^{* *}$ & $129.69^{* *}$ \\
Quadratic & 1 & $1.95^{*}$ & $9.32^{\text {ns }}$ & $2.73^{\text {ns }}$ & $4.17^{\text {ns }}$ \\
Deviation & 4 & $0.55^{\text {ns }}$ & $31.66^{\text {ns }}$ & $12.92^{\text {ns }}$ & $8.06^{\text {ns }}$ \\
Residue & 21 & 0.25 & 10.2056 & 9.44 & 4.34 \\
\hline C.V $(\%)$ & - & 18.76 & 20.12 & 24.80 & 26.33 \\
\hline
\end{tabular}

Results of ANOVAs, with the F test (F) significance, are shown: ** $\mathrm{P}<0.01, * \mathrm{P}<0.05, \mathrm{~ns} \mathrm{P}>0.05$; CV $(\%)=$ Coefficient of Variation. Source: Elaboration of the authors.

Figure 5. Accumulation curves of $\mathrm{Cu}, \mathrm{Fe}, \mathrm{Mn}$, and $\mathrm{Zn}\left(\mathrm{g} \mathrm{ha}^{-1}\right)$ by the physic nut fruits in different phases of growth.
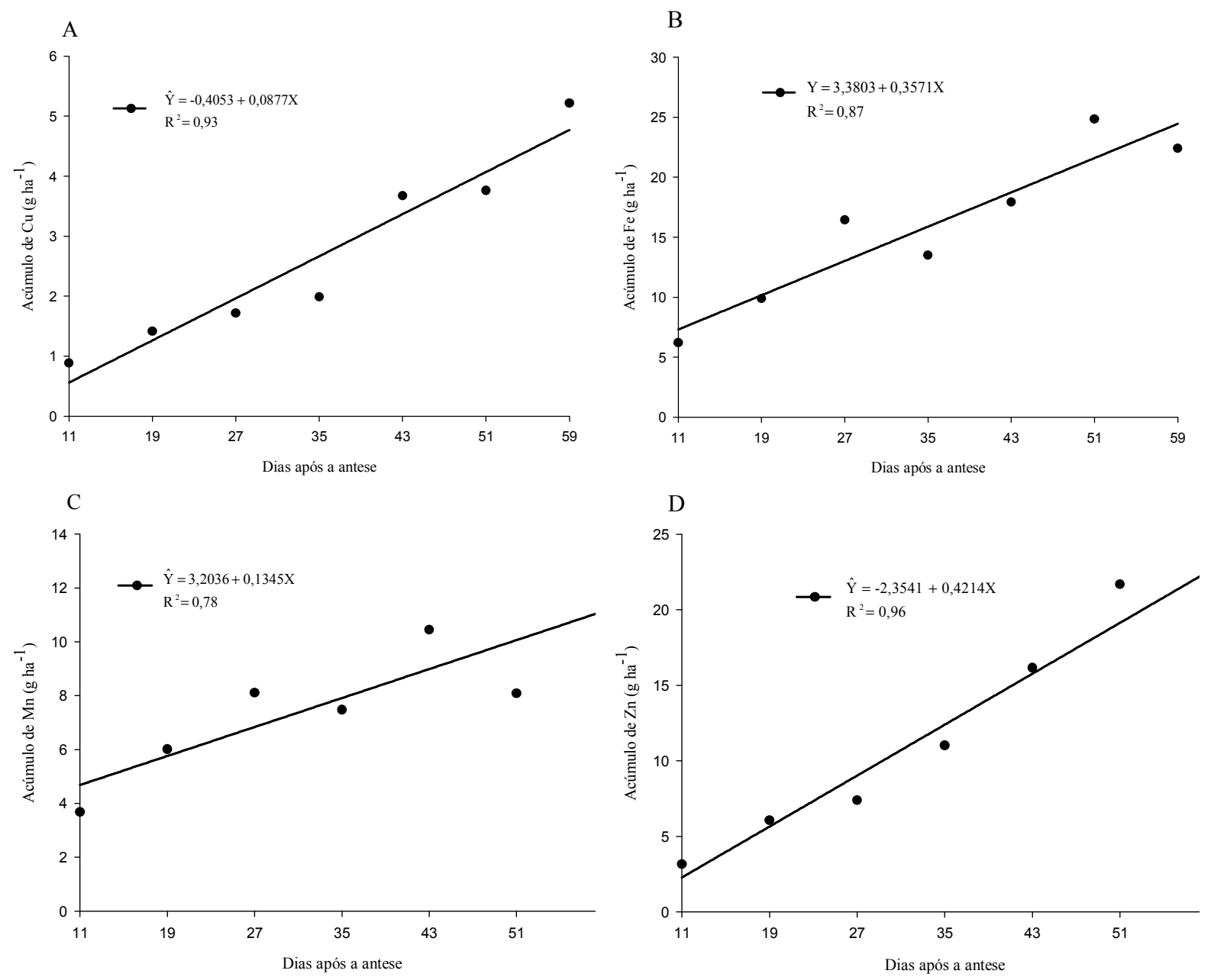

Source: Elaboration of the authors. 
It is likely that the metabolic demand for these three micronutrients began long before the growth phase in the beginning of the fecundation stage and initial formation of the fruit. It is likely that the higher accumulation of $\mathrm{Cu}, \mathrm{Fe}, \mathrm{Mn}$, and $\mathrm{Zn}$ in the fruit-set stage is associated to the importance of these micronutrients in the cellular division processes and membrane stabilization of the newly formed cells (MARSCHNER, 2002; MARENCO and LOPES, 2005). In addition, it is believed that recycling and synthesis of enzymes and intermediate compounds, which were previously used in the synthesis of wall polymers, may occur, and the compounds could be used as precursors in the synthesis of reserve compounds during the endosperm filling process (TAIZ and ZEIGER, 2009). Because micronutrients have an important role in the activation of enzymes, it is possible that the continuous accumulation of micronutrients soon after fecundation and formation of the fruit occurs in response to the increasing metabolic demand for these elements (MARSCHNER, 2002).

With regard to nutrient quantities extracted by the plant parts collected at harvest, we observed that in terms of percentage (Table 4), the seeds extracted the highest amount of minerals when compared to the total amount of minerals extracted by the fruits. We observed that only $\mathrm{K}$ was extracted at a higher level by the hulls when compared to the seeds. These results suggest that the hulls of the physic nut fruits may be reused in the cultivation process as a source of potassium for plants through organic fertilization.

Table 4. Export of macro- and micronutrients through fruit hull, seed, and whole fruits of the physic nut.

\begin{tabular}{|c|c|c|c|c|c|c|c|c|c|c|}
\hline \multirow{2}{*}{$\begin{array}{l}\text { Parts } \\
\text { fruit }\end{array}$} & $\mathrm{N}$ & $\mathrm{P}$ & $\mathrm{K}$ & $\mathrm{Ca}$ & $\mathrm{Mg}$ & $\mathrm{S}$ & $\mathrm{Cu}$ & $\mathrm{Fe}$ & $\mathrm{Zn}$ & $\mathrm{Mn}$ \\
\hline & \multicolumn{5}{|c|}{------------------------------kg ha'-1------------------- } & \multicolumn{5}{|c|}{-------------------'g ha'1------------------ } \\
\hline Hull & 7.3 & 0.7 & 18.6 & 4.2 & 2.8 & 0.4 & 3.4 & 53.4 & 9.6 & 12.3 \\
\hline Seed & 49.0 & 10.6 & 7.7 & 13.4 & 10.2 & 2.5 & 30.3 & 107.9 & 30.2 & 73.2 \\
\hline Fruit & 56.2 & 11.4 & 26.3 & 17.6 & 13.0 & 2.9 & 33.7 & 161.3 & 39.8 & 85.5 \\
\hline \multirow{2}{*}{$\begin{array}{l}\text { Parts } \\
\text { fruit }\end{array}$} & $\mathrm{N}$ & $\mathrm{P}$ & $\mathrm{K}$ & $\mathrm{Ca}$ & $\mathrm{Mg}$ & $\mathrm{S}$ & $\mathrm{Cu}$ & $\mathrm{Fe}$ & $\mathrm{Zn}$ & $\mathrm{Mn}$ \\
\hline & \multicolumn{10}{|c|}{ Percentage compared to the total extracted amount by the fruit } \\
\hline Hull & 12.9 & 6.6 & 70.8 & 23.8 & 21.5 & 14.0 & 10.1 & 33.1 & 24.2 & 14.4 \\
\hline Seed & 87.1 & 93.4 & 29.2 & 76.2 & 78.5 & 86.0 & 89.9 & 66.9 & 75.8 & 85.6 \\
\hline
\end{tabular}

Source: Elaboration of the authors.

Overall, additional research is needed to study the nutritional status of the physic nut plant and to assess the nutrient quantity exported by fruits. This is particularly important, since among all factors influencing production, nutrition usually assumes greater importance and limits the most the increase of crop productivity. The nutrition demands of the physic nut plant during the production cycle are insufficiently studied, and thus, mineral fertilization is performed based on empirical information. Therefore, the knowledge on nutrient content in plants, particularly in the exported parts, is important to evaluate the removal of these elements from the cultivation area, and is becoming one of the required components for future economic recommendations in fertilization. By conducting fieldwork, we may gain better insight into the physiological performance of plants during their production cycle. Therefore, nutrient extraction across the fruit growth phase will indicate the season in which a plant absorbs nutrients in high or low quantities, and will allow monitoring of the plant's development during the production cycle.

Overall, the accumulation of $\mathrm{N}, \mathrm{P}, \mathrm{K}, \mathrm{S}$, and Fe were low in the first phase of fruit growth, accelerated after 27 DAA, and reached the 
highest point at maturation. We observed an opposite behavior for the remaining nutrients due to, probably, higher metabolic demand for these nutrients in the beginning phase of fecundation, cellular differentiation, division, expansion, and elongation. Given the results presented in this study, a proper planning of fertilization based on the peaks of nutrient accumulation in the fruits is required in order to meet the nutritional demands of fruit production.

\section{Conclusions}

The accumulation of nutrients in physic nut fruits increased with fruit growth.

Nitrogen was the nutrient that accumulated in the highest quantity, followed by potassium, calcium, phosphorus, magnesium, and sulfur. Among micronutrients, the order of accumulation in the fruits was the following: zinc, manganese, copper, and iron.

In the first phase of the physic nut fruit growth, there was an increased requirement for $\mathrm{Ca}, \mathrm{Mg}, \mathrm{Cu}$, $\mathrm{Zn}$, and $\mathrm{Mn}$.

Physic nut plant requires significant amounts of micronutrients during fruit formation.

The main nutrient extracted from the physic nut fruit hull was potassium.

\section{Acknowledgements}

We acknowledge the National Counsel of Technological and Scientific Development (CNPq) for awarding the first author with a PNPD scholarship.

\section{References}

CUEVAS, V. G. Growth performance of Jatropha curas L. Seedlings and some properties of acidic, low fertility grassland soil amended with biowaste compost. The Philippine Agricultural Scientist, Philippines, v. 92, n. 3, p. 315-319, 2009.
DRUMOND, M. A.; SANTOS, C. A. F.; OLIVEIRA, V. R.; MARTINS, J. C.; ANJOS, J. B. O.; EVANGELISTA, M. R. V. Desempenho Agronômico de genótipos de pinhão-manso no semiárido pernambucano. Ciência Rural, Santa Maria, v. 40, n. 1, p. 44-47, 2010.

GRANGEIRO, L. S.; CECÍLIO FILHO, A. B. Acúmulo e exportação de macronutrientes em melancia sem sementes. Horticultura Brasileira, Brasília, v. 23, n. 3, p. 763-767, 2005.

JACKSON, M. L. Soil chemical analysis. New Jersey: Prentice Hall, 1965. 498 p.

JUWARKAR, A. A.; YADAU, S. K.; KUMAR, P.; SINGH, S. K. Effect of biosludge and biofertilizer amendment on growth of Jatropha curcas in heavy metal contaminated soils. Environmental Monitoring and Assessment, Maine, v. 145, n. 1-3, p. 7-15, 2008.

KUMAR, A.; SHARMA, S.; MISHRA, S. Application of farmyard manure and vermicompost on vegetative and generative characteristics of Jatropha curcas. Journal of Phytology, Humnabad, v. 1, n. 4, p. 206-212, 2009.

LAVIOLA, B. G.; DIAS, L. A. S. Teor e acúmulo de nutrientes em folhas e frutos de pinhão-manso. Revista Brasileira de Ciência do Solo, Viçosa, v. 32, n. 5, p. 1969-1975, 2008.

LIMA, R. L. S.; FERREIRA, G. B.; AZEVEDO, C. A. V.; ARRIEL, N. H. C.; LUCENA, A. M. A. Determinação do número ótimo de plantas e folhas para caracterização nutricional do pinhão-manso. In: CONGRESSO BRASILEIRO DE PINHÃO-MANSO, 2., 2011, Brasília. Anais... Brasília: Associação Brasileira de Pesquisa do Pinhão-Manso, 2011c. CD-ROM.

LIMA, R. L. S.; SEVERINO, L. S.; CAZETTA, J. O.; AZEVEDO, C. A. V.; SOFIATTI, V.; ARRIEL, N. H. C. Redistribuição de nutrientes em folhas de pinhãomanso entre estádios fenológicos. Revista Brasileira de Engenharia Agrícola e Ambiental, Campina Grande, v. 15, n. 11, p. 1175-1179, 2011 b.

LIMA, R. L. S.; SEVERINO, L. S.; GHEYI, H. R.; SOFIATTI, V.; ARRIEL, N. H. C. Efeito da adubação fosfatada sobre o crescimento e teor de macronutrientes de mudas de pinhão-manso. Revista Ciência Agronômica, Fortaleza, v. 42, n. 4, p. 950-956, 2011 a.

MAES, W. H.; TRABUCCO, A.; ACHTEN, W. M. J.; MUYS, B. Climatic growing conditions of Jatrophacurcas L. Biomass and Bioenergy, Oxford, v. 33, n. 10, p. 1481-1485, 2009. 
MAIA, J. T. L. S.; GUILHERME, D. O.; PAULINO, M. A. O.; SILVEIRA, H. R. O.; FERNANDES, L. A. Efeito da omissão de macro e micronutrientes no crescimento de pinhão-manso. Revista Caatinga, Mossoró, v. 24, n. 2, p. 174-179, 2011.

MALAVOLTA, E.; VITTI, G. C.; OLIVEIRA, S. A. Avaliação do estado nutricional das plantas: princípios e aplicações. Piracicaba: Potafos, 1997. 319 p.

MARSCHNER, H. Mineral nutrition of higher plants. London: Academic, 2002. 889 p.

MARTINS, L. D.; NOGUEIRA, N. O.; TOMAZ, M. A.; AMARAL, J. F. T.; LAVIOLA, B. G. Efeito do corretivo escória de siderurgia e diferentes adubações no teor nutricional de folhas de mamona e pinhão-manso. Revista Verde, Mossoró, v. 4, n. 4, p. 135-145, 2009.

MESQUITA, E. F.; CAVALCANTE, L. F.; GONDIM, S. C.; CAMPOS, V. B.; CAVALCANTE, I. H. L.; GONDIM, P. B. Teores foliares e exportação de nutrientes do mamoeiro baixinho de Santa Amália tratado com biofertilizantes. Pesquisa Agropecuária Tropical, Goiás, v. 40, n. 1, p. 66-76, 2010.

MOURA, F. T.; SILVA, S. M.; MARTINS, L. P.; MENDONÇA, R. M. N. Evolução do crescimento e da maturação de frutos de cajazeira (Spondias mombin L.). Proceedings of the Inter American Society for Tropical. Fruit/Frutales, Homostead, v. 47, p. 231-233, 2003.

NOOR CAMELLIA, N. A.; THOHIRAH, L. A.; ABDULLAH, N. A. P.; MOHD KHIDIR, O. Improvement on rooting quality of Jatropha curcas using indole butyrico acid (IAB). Research Journal of Agriculture and Biological Sciences, Jordan, v. 5, n. 4, p. 338-343, 2009.

PEREIRA, J. C. S.; FIDELIS, R. R.; ERASMO, E. A. L.; SANTOS, P. M.; BARROS, H. B.; CARVALHO, G. L. Florescimento e frutificação de genótipos de pinhãomanso sob doses de fósforo no cerrado da Região Sul do Tocantins. Journal of Biotechnology and Biodiversity, Gurupi, v. 2, n. 2, p. 28-36, 2011.

PRATES, F. B. S.; LUCAS, C. S. G.; SAMPAIO, R. A.; BRANDÃO JÚNIOR, D. S.; FERNANDES, L. A.; ZUBA JÚNIOR, G. R. Crescimento de mudas de pinhãomanso em resposta a adubação com superfosfato simples e pó-de-rocha. Revista Ciência Agronômica, Fortaleza, v. 43, n. 2, p. 207-213, 2012.
RAMÍREZ, F.; BERTSCH, F.; MORA, L. Consumo de nutrimentos por los frutos y bandolas de cafe Caturra durante um ciclo de desarrollo y maduracion en Aquiares, Turrialba. Agronomía Costarricence, Costa Rica, v. 26, n. 1, p. 33-42, 2002.

RENA, A. B.; BARROS, R. S.; MAESTRI, M. Desenvolvimento reprodutivo do cafeeiro. In: ZAMBOLIM, L. (Org.). Tecnologias de produção de café com qualidade. Viçosa, MG: Universidade Federal de Viçosa, 2001. p. 101-128.

SANTOS, C. M.; ENDRES, L.; WANDERLEY FILHO, H. C. L.; ROLIM, E. V.; FERREIRA, V. M. Fenologia e crescimento do pinhão-manso cultivado na zona da Mata do Estado de Alagoas, Brasil. Scientia Agrária, Curitiba, v. 11, n. 3, p. 201-209, 2010.

SANTOS, J. W. dos; ALMEIDA, F. de A. C.; BELTRÃO, N. E. DE M.; CAVALCANTE, F. B. Estatística experimental aplicada. 2. ed. rev. ampl. Campina Grande: Embrapa Algodão/UFCG, 2008. 461 p.

SILVA, A. P.; MORAIS, D. L. P.; KAKIDA, J.; FERREIRA, E. A.; SILVA, V. F. Concentração do ciclo de produção de pinhão-manso por meio de podas de formação ou de produção. Revista Pesquisa Agropecuária Brasileira, Brasília, v. 47, p. 134-137, 2012.

SILVA, E. B.; TANUELI, L. P. P.; SANTOS, S. R.; REZENDE JÚNIOR, P. S. Sintomas visuais de deficiências nutricionais em pinhão-manso. Pesquisa Agropecuária Brasileira, Brasília, v. 44, n. 4, p. 392-397, 2009.

SOUSA, A. E. C.; GHEYI, H. R.; SOARES, F. A. L.; NOBRE, R. G.; NASCIMENTO, E. C. S. Componentes de produção de pinhão-manso irrigado com água de diferentes condutividades elétricas e doses de fósforo. Ciência Rural, Santa Maria, v. 42, n. 6, p. 1007-1012, 2012.

SOUZA, P. T.; SILVA, E. B.; GRAZZIOTTI, P. H.; FERNANDEZ, L. A. NPK Fertilization on initial growth of physic nut seedlings in quartzarenic neossol. Revista Brasileira de Ciência do Solo, Viçosa, MG, v. 35, n. 2, p. 559-566, 2011.

TAIZ, L.; ZEIGER, E. Fisiologia vegetal. 5. ed. Porto Alegre: Artmed, 2013. 954 p. 